\title{
A rare case of aggressive angiomyxoma of vulva since childhood
}

\author{
Shankar B. Burute ${ }^{1}$, T. Swetha Jahnavi ${ }^{1}$, Karuna Ratwani ${ }^{1 *}$, \\ Arpana A. Dharwadkar' ${ }^{2}$, Jayashree P. Kulkarni ${ }^{1}$
}

\author{
${ }^{1}$ Department of Obstetrics \& Gynaecology, DY Patil Medical College, Pune, Maharashtra, India \\ ${ }^{2}$ Department of Pathology, DY Patil Medical College, Pune, Maharashtra, India
}

Received: 5 August 2014

Accepted: 19 August 2014

\author{
*Correspondence: \\ Dr. Karuna Ratwani, \\ E-mail: karuna.ratwani@gmail.com
}

(C) 2014 Burute SB et al. This is an open-access article distributed under the terms of the Creative Commons Attribution Non-Commercial License, which permits unrestricted non-commercial use, distribution, and reproduction in any medium, provided the original work is properly cited.

\begin{abstract}
Aggressive angiomyxoma is a locally invasive benign mesenchymal tumour usually occurring in women of reproductive age and is rare in children. It carries a high risk of recurrence and hence needs to be differentiated from other masses. The diagnosis is difficult clinically and is almost always histological. Here is a rare case of aggressive angiomyxoma of vulva in a 15 year old female presented with presented with mass in vulva on left side since birth and increased to the present size since 3 years. The swelling was painless, no local rise of temperature, no visible veins. Attained menarche 2 years ago and cycles are regular with normal flow.
\end{abstract}

Keywords: Aggressive angiomyxoma, Mesenchymal tumors, Vulval mass

\section{INTRODUCTION}

Aggressive angiomyxoma was first described by Steeper and Rosai in $1983^{1}$ around 250 cases are reported till date. Due to its slow and insidious growth and a high risk of relapse it is called aggressive. It usually affects females of reproductive age and rarely males with a ratio of $6: 1 .^{2}$

It usually appears in the pelvic and perineal region and may be clinically misdiagnosed as polyps, lipoma, vulvar abscess, perineal hernia, Bartholins cyst, Gartners duct cyst, vaginal cyst and other benign and malignant soft tissue tumors like leiomyoma, myxolipoma, myxoidmneurofibroma, malignant fibrous histiocytoma. In males it may originate from spermatic cord scrotum epidydimus and inguinal region mimiking hydrocoele or inguinal hernia. ${ }^{3,4}$

If not treated it may displace or invade surrounding organs like bladder and rectum. Surgical excision as an en-bloc specimen is the main stay of treatment though life time follow-up to monitor for recurrences is mandatory.

\section{CASE REPORT}

A 15 year old nulligravida presented with mass in vulva on left side since birth and increased to the present size since 3 years. The swelling was painless, no local rise of temperature, no visible veins. Attained menarche 2 years ago and cycles are regular with normal flow. On examination vitals were normal and secondary sexual characters well developed. Local examination revealed pedunculated swelling over left vulva $7 \times 6 \times 4 \mathrm{~cm}$. skin over the swelling appeared normal. Swelling soft to firm in consistency, nonpulsatile, nonfluctuant and, nonreducible. No regional lymph nodes palpable. All routine blood investigations in normal limits. USG of pelvis revealed normal sized uterus and adnexa. USG of perineum demonstrated significant vascularity in the swelling. FNAC was done twice but reports were inconclusive due to haemorrhagic aspirate. MRI showed large exophytic lesion from base of transverse perineal muscle, $6.5 \times 5 \times 5 \mathrm{~cm}$ displacing the surrounding structures but no infiltration seen more likely to be angiomyxoma of vulva. 
Wide excision of the mass was done under spinal anesthesia. Gross appearance- cut surface was homogenous glistening with no obvious hemorrhage or necrosis. HPE report showed loosely scattered spindle shaped cells with ill-defined cytoplasm and oval hyperchromatic nucleus, thick and thin walled vascular channels in a myxoid stroma rich in collagen fibres $\mathrm{S} / \mathrm{O}$ aggressive angiomyxoma. Though the patient doesn't fit in to the age group, considering the histological features diagnosis was confirmed.

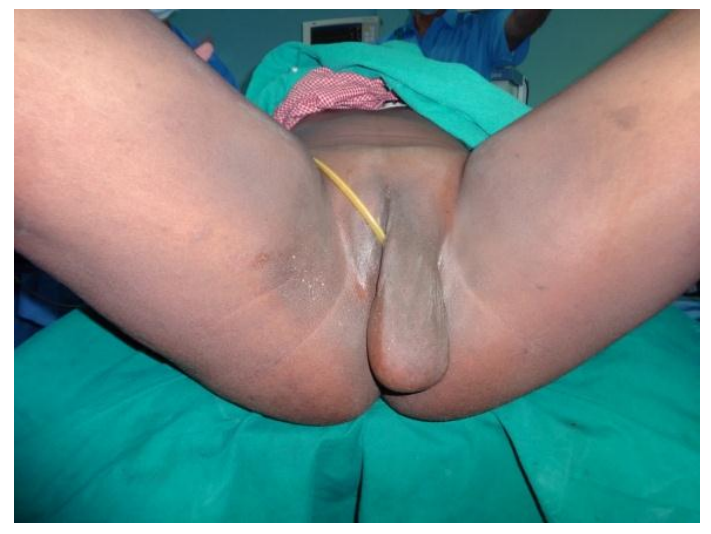

Figure 1: Pedunculated vulvar swelling.

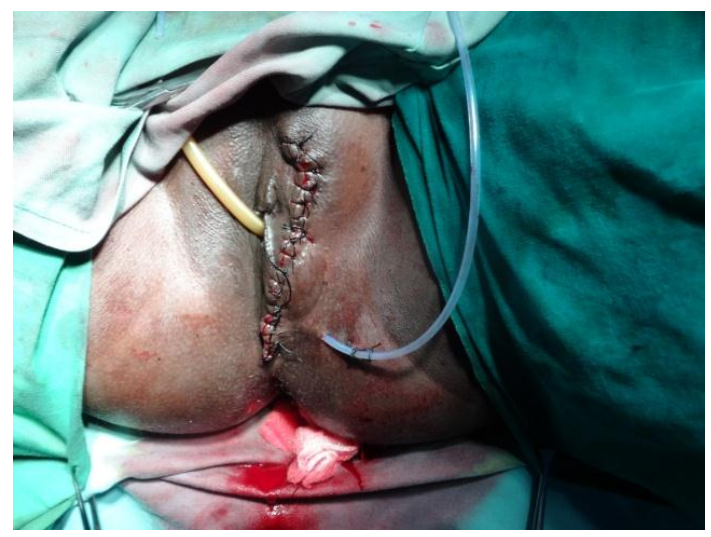

Figure 2: After excision of the mass.

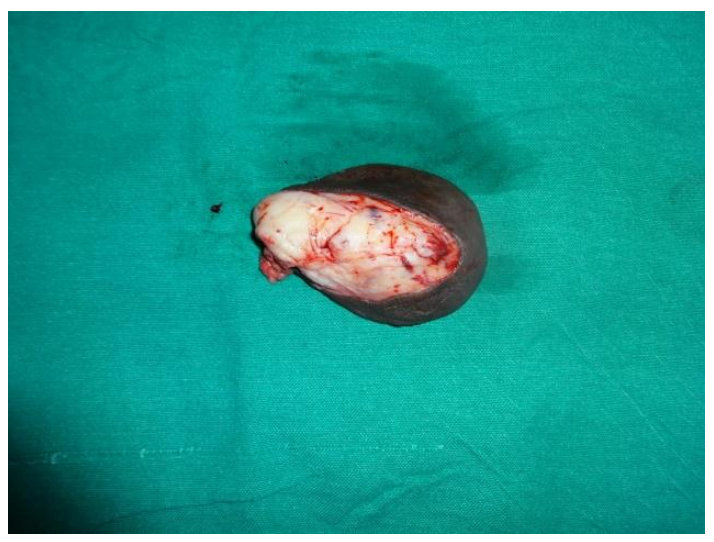

Figure 3: Cut surface of mass showing homogenous gelatinous glistening substance with no obvious haemorrhage or necrosis.

\section{DISCUSSION}

Aggressive angiomyxoma is a locally invasive benign mesenchymal tumour usually occurring in women of reproductive age and is rare in children. High rates of angiomyxoma were reported in skeletal muscles. ${ }^{5}$ Rare cases were reported in larynx, ${ }^{6}$ lung, ${ }^{7}$ maxillary sinus, ${ }^{8}$ jejunum ${ }^{9}$ and bladder. ${ }^{10}$ In females it is common in the perineal and pelvic regions. In males it usually involves scrotum, inguinal region, perineum and rarely spermatic cord and epididymis. Male:female ratio of 1:6.

The etiopathogenesis is unknown. It is believed to arise from specialised mesenchymal cells of pelvic-perineal region or from the multipotent perivascular progenitor cells which often display variable myofibroblastic and fibroblastic features. ${ }^{11}$ This hypothesis is supported by the fact that the tumor cells express desmin and sometimes actin. The tumor may have estrogen and progesterone receptors and is hormonally responsive. ${ }^{12}$ During pregnancy progesterone receptors were strongly positive whereas estrogen receptors are negative. ${ }^{13,14}$ In males tumors showed receptors for androgen and progesterone. $^{15}$

Chromosomal abnormalities like translocation 12$21[46, \mathrm{XX}, \mathrm{t}(12 ; 21)(\mathrm{q} 15 ; \mathrm{q} 21.1)]$ and rearrangement of $\mathrm{HMGA}_{2}$ gene were detected on cytological studies. ${ }^{8}$ Cytogenetic studies help to differentiate it from its less aggressive histological mimics.

Treatment is usually wide excision as an en-bloc specimen. When bladder or rectum is attached to the mass, extensive surgery may not be justified due to its high recurrence rates. In young patients, who desire fertility, incomplete recurrence is justifiable and local recurrences are treated with further resection. ${ }^{16}$

Chemotherapy and radiotherapy are ineffective due to the low proliferative potential of the cells, but high dose radiotherapy has been used successfully to treat recurrent disease. For tumors that are positive for estrogen and progesterone receptors, recurrences can be treated with GNRH inhibitors like leuprolide. ${ }^{17}$ SERM such as raloxifene have also been used. Preoperative angiographic embolization, ${ }^{18}$ external beam irradiation, and intra operative electron beam radiotherapy have been used to decrease local recurrence. ${ }^{19}$

Recurrences may occur from months to years with maximal incidence during the first two years (70\%), though cases have been reported with recurrences after 8 years $^{20}$ and 20 years. ${ }^{21,22}$ Therefore all cases should be followed minimum upto 2 years though lifetime follow up is warranted.

Funding: No funding sources

Conflict of interest: None declared

Ethical approval: Not required 


\section{REFERENCES}

1. Steeper TA, Rosai J. Aggressive angiomyxoma of the female pelvis and perineum. Report of nine cases a distinctive type of gynecologic soft-tissue neoplasm. Am J Surg Pathol. 1983;7:463-75.

2. Chan YM, Hon E, Ngai SW, Ng TY, Wong LC. Aggressive angiomyxoma in females: is radical resection the only option? Acta Obstet Gynaecol Scand. 2000;79:216-20.

3. Minagawa T, Matsushita K, Shimada R, Takayama H, Hiraga R. Aggressive angiomyxoma mimicking inguinal hernia in a man. Int $\mathrm{J}$ Clin Oncol. 2009;14:365-8.

4. Morag R, Fridman E, Mor Y. Aggressive angiomyxoma of the scrotum mimicking huge hydrocele: case report and literature review. Case Rep Med. 2009;2009:157624.

5. Rosai J. Angiomyxoma. In: Rosai J, eds. Rosai and Ackerman's Surgical Pathology. 9th ed. New York: Mosby (Elsevier); 2005: 2316-2317.

6. Sylvester DC, Kortequee S, Moor JW, Woodhead CJ, Maclennan KA. Aggressive angiomyxoma of larynx: case report and literature review. J Laryngol Otol. 2010;124:793-5.

7. Choi YD, Kim JH, Nam JH, Choi C, Na KJ, Song SY. Aggressive angiomyxoma of the lung. J Clin Pathol. 2008;61:962-4.

8. Rawlinson NJ, West WW, Nelson M, Bridge JA. Aggressive angiomyxoma with $\mathrm{t}(12 ; 21)$ and HMGA2 rearrangement: report of a case and review of the literature. Cancer Genet Cytogenet. 2008;181:119-24.

9. Tiwari N, Magu SK, Ghoshal UC, Sharma AK. Aggressive angiomyxoma of the jejunum: a rare cause of obscure gastrointestinal bleeding. Trop Gastroenterol. 2007;28:183-5.

10. May F, Luther A, Mohr W, Bachor R, Hautmann RE. Recurrent aggressive angiomyxoma of the urinary bladder. Case report and review of the literature. Urol Int. 2000;65:57-9.

11. Alameda F, Munne A, Baro T, Iglesias M, Condom E, Lloreta-Trull J, et al. Vulvar angiomyxoma, aggressive angiomyxoma and angiomyofibroblastoma: an immunohistochemical and ultrastructural study. Ultrastruct Pathol. 2006;30:193-205.
12. Mc Cluggage WG, Patterson A, Maxwell P. Aggressive angiomyxoma of pelvic parts exhibits oestrogen and progesterone receptor positivity. J Clin Pathol. 2000;53:603-5.

13. Htwe M, Deppisch LM, Saint-Julien JS. Hormonedependent, aggressive angiomyxoma of the vulva. Obstet Gynaecol. 1995;86:697-9.

14. Aye C, Jefferis H, Chung DY, Manek S, Kehoe S. A case of multi-modal managed vulval aggressive angiomyxoma diagnosed before conception and monitored during pregnancy. Gynaecol Oncol. 2009;115:170-1.

15. Chihara Y, Fujimoto K, Takada S, Hirayama A, Cho M, Yoshida K, et al. Aggressive angiomyxoma in the scrotum expressing androgen and progesterone receptors. Int J Urol. 2003;10:672-5.

16. Outwater EK, Marchetto BE, Wagner BJ, Siegelman ES. Aggressive angiomyxoma: findings on CT and MR imaging. AJR Am J Roentgenol. 1999;172:4358.

17. McCluggage WG, Jamieson T, Dobbs SP, Grey A. Aggressive angiomyxoma of the vulva: dramatic response to gonadotropin-releasing hormone agonist therapy. Gynaecol Oncol. 2006;100:623-5.

18. Magtibay PM, Salmon Z, Keeney GL, Podratz KC. Aggressive angiomyxoma of the female pelvis and perineum: a case series. Int $\mathbf{J}$ Gynaecol Cancer. 2006;16:396-401.

19. Nyam DC, Pemberton JH. Large aggressive angiomyxoma of the perineum and pelvis: an alternative approach. Report of a case. Dis Colon Rectum. 1998;41:514-6.

20. Salman MC, Kuzey GM, Dogan NU, Yuce K. Aggressive angiomyxoma of vulva recurring 8 years after initial diagnosis. Arch Gynaecol Obstet. 2009;280:485-7.

21. Behranwala KA, Latifaj B, Blake P, Barton DP, Shepherd JH, Thomas JM. Vulvar soft tissue tumors. Int J Gynaecol Cancer. 2004;14:94-9.

22. Ribaldone R, Piantanida P, Surico D, Boldrini R, Colombo N, Surico N. Aggressive angiomyxoma of the vulva. Gynaecol Oncol. 2004;95:724-8.

DOI: $10.5455 / 2320-1770$. ijrcog20140972

Cite this article as: Burute SB, Swetha Jahnavi T, Ratwani K, Dharwadkar AA, Kulkarni JP. A rare case of aggressive angiomyxoma of vulva since childhood. Int J Reprod Contracept Obstet Gynecol 2014;3:851-3. 